\title{
A STUDY OF SELECTION OF MUTUAL FUND SCHEMES BY INVESTORS
}

\author{
Mr. C. Praveen Kumar Reddy, \\ Principal \& Asst. Professor, \\ OU PG College, Vikarabad.Ranga Reddy District \\ cpraveen_323@yahoo.co.in
}

\begin{abstract}
Indian mutual fund has gained a lot of popularity from the past few years. Earlier only UTI enjoyed the monopoly in this industry, but with the passage of time many new players entered the market, due to which the UTI monopoly breaks down and the industry faces a severe competition. As the time passes this industry has become a buzz word in the Indian financial system. So it is very important to know the investors' perception about this industry. The present Paper presents a selection of Mutual fund schemes by the investor. The Selection of Mutual fund Schemes based on different qualities Sponsor, Fund, Investor related qualities and also this paper makes an attempt to identify various factors affecting perception of investors regarding investment in Mutual funds. It will help the MF companies to create new and innovative product according to the orientation of investors. The research generated few factors affecting perception of investors regarding mutual fund selection, which vary from one to another.
\end{abstract}

KEYWORDS: Mutual fund, investors' perception, investors' behavior.

INTRODUCTION: The financial markets play a crucial role in the economic development of a country by facilitating the allocation of scarce resources from the savers to the borrowers it directs resources from the idler to the productive sector thus accelerating investment in the economy.

The Economic and financial scenario of India Prior to 1991 was not optimistic. Indian Economy was suffering from low savings GDP high inflation, high unemployment, high rate of interest low Forex reserve. The Major reforms are taking place in the financial sector with the introduction of liberalization privatization and globalization. The way of economic reforms initiated by the government has influenced the functioning and governance of the capital market. The Indian Capital market is also undergoing structural transformation since liberalization in the year 1991. The Indian capital market has witnessed development and improvements in terms of various parameters improve market efficiency market stock market transaction are more transparent curb unfair trade practices and to bring our financial market up to international standards 
ELK

Asia Pacific Journals

consistence reforms in Indian capital market in the secondary market resulting in modern technology and online trading have revolutionized the stock exchanges. The wave of economic reforms initiated by the government has influenced the functioning and governance of the capital market. The financial system is India Comprises of the financial institution, financial markets, financial instruments and services. Financial assets represent a claim for the payment of principle amount some time in the future date and for periodic payment of money in the form of interest and dividend. The RBI as the main regulator of credit is the apex Institutions in the financial system other important financial institutions are the commercial banking (Public and Private) Co-operative banks, regional rural banks and development bank. Non-bank financial institutions include finance and leasing Companies and other institutions LIC GIC UTI MF PF Bank. Indian financial reforms aim at improving the productivity and efficiency of the economy. The opening of the Indian financial market to foreign and Private Indian Player has resulted in increased competition and better product offerings to consumers. The main function of all these financial institutions is financial
ELK Asia Pacific Journals - Special Issue

ISBN: 978-81-930411-9-2

intermediation facilitating the flow of saving from common man to industrial houses. In the initial stage the role of intermediary was mostly related to ensure transfer of funds from the lender to the borrower. The financial system widened along with the development taking place in the financial markets. The scope of its operation also widened the important intermediaries operating in the financial markets include Investment banks, Underwriters, Stock exchange resister, depositories, Custodian, Portfolio Managers Mutual funds.

The Indian capital market has also experienced a process of structural transformation with operations conducted to standards equivalent to those in the developed markets. It was opened up for investment to FIIs in 1992 and Indian companies were allowed to raise resources abroad through Global Depository Receipts, American Depository Receipts, Foreign currency Convertible Bonds, the primary and secondary segments of the capital markets have expanded rapidly with greater institutionalization and wider participation of individual investor accompanying this growth. There has been an emergence of new instruments Futures, Options in the 
ELK

Asia Pacific Journals

capital markets to reduce the risk associated are both growing.

The increasing volatility in the market has also motivated the investors to invest in another relatively safe vehicle of investment. A lot of variants to standard mutual funds have come like exchange traded funds, fund of funds as on Mutual fund is single large professionally managed investment organization that combines the money of many individual investors having similar investment objectives mutual fund is an investment institutions which mobilized savings of the individual and institutions and channelizes these savings in corporate securities to provide investor a steady stream of returns and capital appreciation.

\section{REVEW OF LITERATURE: Anjan} Chakarabarti and Harsh Rungta (2000) stressed the importance of the brand effect in determining the competitive position of the AMCs. Their study reveals that brand image factor, though cannot be easily captured by computable performance measures, influences the investor's perception and hence his fund/scheme selection.

De Bond and Thaler (1985) while investigating the possible psychological
ELK Asia Pacific Journals - Special Issue

ISBN: 978-81-930411-9-2

basis for investor behavior, argue that mean reversion in stock prices is an evidence of investor over reaction where investors over emphasize recent firm performance in forming future expectations of the investment.

Nalini and Sasikumar studied about the mutual funds in India. The main objectives of the study were to analyze how the mutual fund schemes help to mobilize savings from the household sector. Mutual funds have now made their presence felt in Indian financial market by mobilizing the savings of household and corporate sectors and deploying the same in the market. The period of study was 1987 - 91. During this period, the share of mutual funds in the household financial savings rose from $2.3 \%$ to $3.5 \%$ and estimates showed that more than $5.6 \%$ of the total financial savings of the Indian public were invested in mutual funds.

Madhusudhan Vs Jambodekar (1996) conducted a study to assess the awareness of MFs among investors, to identify the information sources influencing the buying decision and the factors influencing the choice of a particular fund. The study reveals, among other things, that Income Schemes and Open Ended Schemes are 
ELK

Asia Pacific Journals

more preferred than Growth Schemes and Close Ended Schemes during the then prevalent market conditions. Investors look for safety of Principal, Liquidity and Capital appreciation in the order of importance; Newspapers and Magazines are the first source of information through which investors get to know about MFs/Schemes and investor service is a major differentiating factor in the selection of Mutual Fund Schemes.

Akhilesh Mishra (2008) has done a study on the topic "Mutual Fund as a Better Investment Plan" and states that many of the people have the fear of Mutual Funds. "They think their money will not be secure in Mutual funds," says Mishra. He also says that the investors need the knowledge of Mutual Funds and its related terms. Many of the people have not invested in Mutual funds due to lack of Awareness, although they have money to invest, he adds. Mishra also points out that "Brand" plays an important role for the investment. Only people who invest directly know well about the Mutual fund and its operations, he adds.

\section{OBJECTIVE OF THE STUDY}

To Study the Selection of Mutual Fund Schemes by investors.
ELK Asia Pacific Journals - Special Issue

ISBN: 978-81-930411-9-2

To study the Current attitude towards financial products, facilities provided by the AMFI, Fund Houses are satisfied by the investor.

\section{RESEARCH METHODOLOGY}

PRIMARY DATA: The Responses of individual investors were collected through filled questionnaire with pre explained objective of research. To reduce the complexity of data responses questionnaires were distributed among those investors only who had prior experience of mutual fund investment. For this purpose random sampling was ignored and selective systematic sampling was taken for consideration. For reliability of questionnaire 200 individual investor were selected from different major cities in Ranga reddy district which included selective investors who were assumed to be having completed knowledge of financial environment and further they were existing investor of mutual funds.

\section{STATISTICAL TOOLS}

MEAN SCORE VALUES :Mean score values has been calculated for the different scales used to find the current attitude of the financial products and services provided by 
ELK

Asia Pacific Journals

the AMFI, Fund Houses, Sponsoring agencies.

FACTOR ANALYSIS: The data obtained from the study were analyzed by using factor analysis for identification of the key features preferred by the respondents in the Mutual Fund product selection factor Analysis identifies Common dimensions of factor from the observed variables that have a high correlation with observed ad seemingly unrelated variables $\mathrm{n}$ correlation among the factor. Principal Component Analysis is the Commonly Used Method for grouping the variables under few unrelated factors.

RESULTS AND DISCUSSIONS: They are different qualities that affect the selection of Mutual fund schemes by the investor.24-factors are generated for measuring respondent's opinion on 5-point scale on the selection of Mutual fund schemes. Factor Matrix and their corresponding factor loading after varimax rotation are presented in the analysis way.

Analysis: 1:- LOADING OF SELECTED VARIABLES (LOADING

\section{CRITERIA $>.5$ )}

From the analysis table clearly indicates that the first factor is identified, Fringe benefits,
ELK Asia Pacific Journals - Special Issue

ISBN: 978-81-930411-9-2

Disclosure of deviation of investments from the original pattern, Sponsor experts in managing money, Sponsor has well developed research, Sponsor has well developed agency, Sponsor a past performance in terms of risk and return all these factors are grouped under Factor-1 and termed as Infrastructure facilities of Sponsor.

The Second Factor is identified Entry and Exit load, Reputation of sponsoring firm, Funds reputation, Fund performance record, Schemes expense ratio, Disclosure of investment objective in the advertisement, Schemes portfolio of investment, and all these factors are grouped under Factor- 2 and termed as Fund Reputation.

The Third Factor is Minimum initial investment this grouped under Factor-3 and termed as Flexibility.

The Fourth Factor is Preferred MF to avoid problems, Disclosure of periodicity of valuation in the advertisement, and these factors is grouped under Factor-4 and termed as Transparency.

The Fourth Factor is Sponsor has a recognized brand name, and termed as Brand name of the Sponsor. The Fifth Factor is Withdrawal facilities and termed as Additional facilities. 
ELK

Asia Pacific Journals

Analysis: 2:- CURRENT ATTITUDE TOWARDS FINANCIAL

INSTRUMENTS

The Financial Markets consists of Various financial products that meets the various needs of individual investors the attitude towards financial instruments.

OVERALL MSV=8.63866. The current attitude towards financial instruments high in these instruments Debentures, Mutual fund, Bonds, Post Office Deposits, Real Estate, Real estate all these instruments Mean Score value is greater than Overall Mean Score Value. Except Shares, Gold all these mean Score Value is very less compared to the other financial instruments.

\section{Analysis: 3:- FACILITIES TOWRODS INVESTORS BY AMFI FUND HOUSES}

There are different types of services provided by the different types of fund houses, and AMFI to protect the interest of the investor and attract the more number of investors.

Overall MSV $=9.3910$. The anaysis table clearly indicates facilities provided by the fund houses, AMFI are mostly satisfied by the investors The Mean Score Value is high in these type of services Entry and exit out of Mutual Funds is easy, Ups and many MF
ELK Asia Pacific Journals - Special Issue

ISBN: 978-81-930411-9-2

schemes to meet the varied needs of investors, Mutual fund investing is a best alternative to equity investing, AMFI protects the interests of MF industry and the unit holders., Bank sponsored Mutual Funds give a definite positive return which is greater than Bank fixed deposits rate for a similar period., Investment in MF helps you release the benefits of stock Market.Return of the Principal amount invested in any MF is assured, except in the case these services MF returns and Principal are fully protected and guaranteed by Association of Mutual Funds (AMFI), M F investing gives a definite positive return.

SUMMARY AND CONCLUSIONS: The present study identifies the selection of mutual fund schemes by the investor affected by different factors. 24 factors are identified selection of mutual fund products. The data collected from the different investors those who are having sufficient amount of knowledge about financial Markets especially in Mutual funds. The data collected from the respondents from Ranga Reddy district in Telangana State. The factors identified in the study provides important factors regarding the selection of mutual fund products, the following factor is 
ELK

Asia Pacific Journals

grouped and named into infrastructure, Reputation of fund, flexibility, transparency, additional Facilities,Brand Name.The The Overall Mean Score value towards financial instruments $(8.638 \%)$ is greater Mean Score Value in all financial instruments except Share,Gold. The facilities provided by the fund houses, AMFI highly satisfied by all the investor except MF returns and Principal are fully protected and guaranteed by the Association of Mutual Funds (AMFI).

\section{REFERENCE.}

[1] Bhatt, M. Narayana, “ Setting standards for investor services", Economic Times, 27 Dec.1993.

[2] Ferris, S.P., and D.M.Chance, "The effect of 12b-1 fees on Mutual Fund expense ratio: A Note", The Journal of Finance, 42, 1987, 1077-82.

[3] Kahneman, Daniel and Amos Tversky, "Prospect Theory: An Analysis of Decision Making Under Risk,"Econometrica, 1979.

[4] Kahneman, Daniel and Mark Riepe, "Aspects of Investor Psychology", Journal of Portfolio Management, Summer 1998.

[5] Raja Rajan V "Investment size based segmentation of individual
ELK Asia Pacific Journals - Special Issue ISBN: 978-81-930411-9-2

investors" , Management

Researcher, 1997b, 21-28;

[6] Shankar, V., "Retailing Mutual Funds: A consumer product model", The Hindu, 24 July 1996, 26.

[7] SEBI - NCAER, 2000, Survey of Indian Investors, SEBI, Mumbai. 